\title{
Desiccation Stress and the Effect of Humidity in Mosses
}

\author{
Aina Arinola FAJUKE \\ Awolowo University, Department of Botany, Obafemi Ile-Ife, Nigeria; realaina@yahoo.com
}

\begin{abstract}
Mosses show fair degree of structural adaptations to different environmental conditions. The effects caused by desiccation were determined in the shoots of six moss species, collected from various locations of the Obafemi Awolowo University Ile-Ife campus, Osun State, Nigeria. Using $0.1 \mathrm{~g}$ of fresh weights, desiccation of moss species over time at $0 \%, 52 \%$, and $100 \%$ relative humidity, were determined by putting the shoots into desiccators and reweighing at intervals of $15 \mathrm{~min}, 30 \mathrm{~min}, 1 \mathrm{hr}$ and on the $8^{\text {th }}$ day. It was concluded that the locations of the moss species, and the fact that the cell walls of all the mosses were thick, were regarded as the adaptations which helped these mosses survived desiccation stress.
\end{abstract}

Keywords: Bryophytes, desiccation stress, environment and relative humidity

\section{Introduction}

Bryophytes are less independent of their environment and are more limited in their ecological range than the angiosperms (Muller, 1979). The ability of many species to survive periods of severe drought and relative lack of competition from higher plants enable bryophytes to colonize apparently a wide range of inhospitable surface of gravel, rocks, sand and back of insect (Gradstein et al., 1984; Richards, 1984). The water retention capabilities, and relatively thicker cell walls are adaptations that help mosses retain their viability for a long period of time (Makinde and Fajuke, 2009).

During periods of prolonged water deficit it may not be possible for plants to avert the loss of tugor in the cells, resulting in mechanical stress concomitant with membrane damage, metabolic disruption and damages due to free radicals (Smirnoff, 1993; Bohnert, 1995; Pammenter and Berjak, 1999). Desiccation tolerant mosses however, have the ability to tolerate severe water loss and resume normal physiological functioning on rehydration (Gaff, 1989).

\section{Materials and methods}

The moss species used for this investigation were collected from various locations of the Obafemi Awolowo University Main Campus, Ile-Ife, Nigeria.

The six moss species selected for the investigation are: Archidium obioense Schimp ex. C. Mull, Bryum coronatum Schwaegr, Fissidens subglaucissimus Broth and $\mathrm{Oc}^{-}$ toblehparum albidum Hedw, Racopilum africanum Mitt and Thuidium gratum (P. Beauv.) Jacq.

Using freshly collected mosses, within 12 hours, $0.1 \mathrm{~g}$ of the shoot mosses were weighed and put into desiccators where kept in the dark at $25^{\circ} \mathrm{C}$ and $100 \%, 52 \%$ and $0 \%$ rel- ative humidity, obtained with deionized water, saturated solution of magnesium nitrate and silical gel respectively. Specimen of the mosses were removed from the desiccators at interval of 15 minutes, 30 minutes, 1 hour and on the $8^{\text {th }}$ day and then reweighed.

\section{Results}

The weights of the mosses recorded in Fig. 1 after 15 minutes of desiccation shown Racopilum africanum and Thuidium gratum to have the highest weights with distilled water. This was followed by Fissidens subglaucissimus and then Bryum coronatum which was closely followed by Archidium obioense while Octoblepharum albidum came last.

With Magnesium nitrate after 15 minutes of desiccation, Racopilum africanum had the highest weight and was closely followed by Thuidium gratum then came after Bryum coronatum and Fissidens subglaucissimus. Archidium obioense came up next in weight, while Octoblepharum albidum had the lowest weight in the series.

The weight with silica gel after 15 minutes of desiccation showed Racopilum africanum and Thuidium gratum as having the highest weight, followed by Fissidens subglaucissimus. This was closely followed by Archidium obioense, while Bryum coronatum and Octoblepharum albidum came last.

Fig. 1 showes the recorded weights of the six mosses after 30 minutes of desiccation. Racopilum africanum noted the highest weight with distilled water and was followed by Thuidium gratum. Fissidens subglaucissimus came next and was followed by Bryum coronatum. Coming next after this was Archidium obioense while Octoblepharum albidum came last in it weight. 


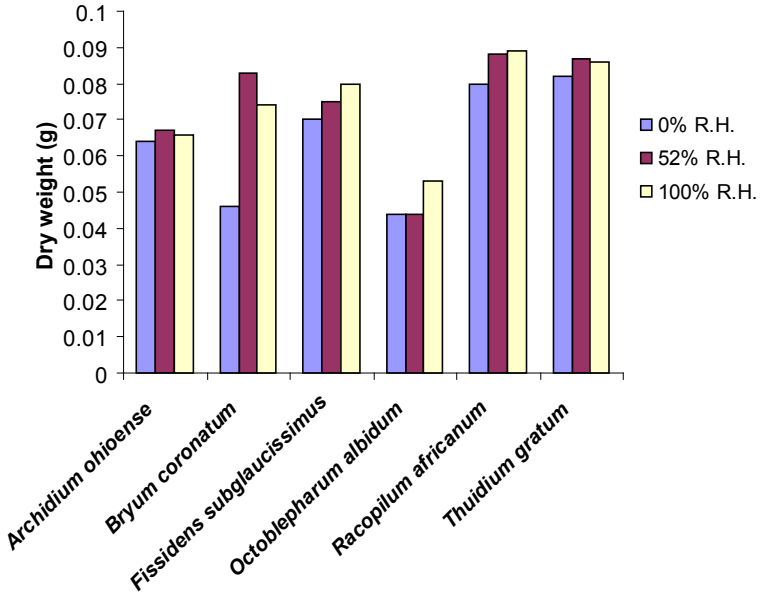

After 15 minutes

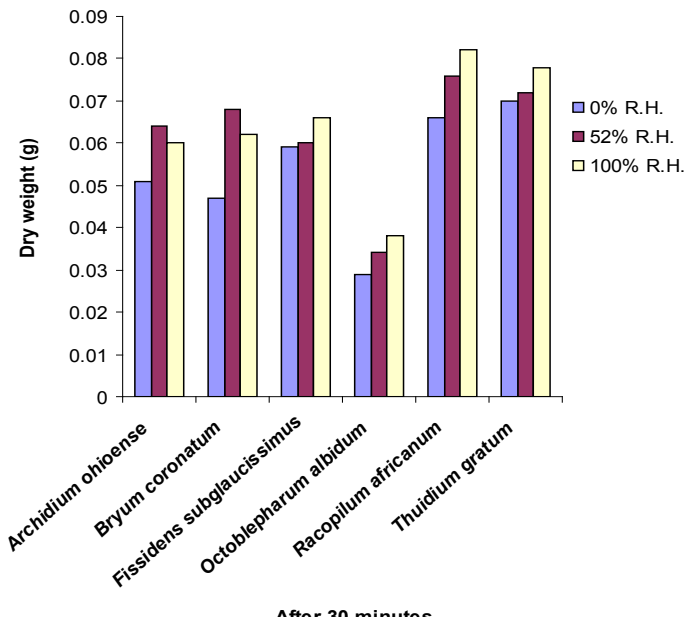

After 30 minutes

Fig. 1. Desiccation resistance in selected mosses

The desiccation of the mosses after 30 minutes with magnesium nitrate showed Racopilum africanum having the highest weight and was followed by Thuidium gratum. Bryum coronatum came next in weight and following this was Archidium obioense. Fissidens subglaucissimus came next to this while Octoblepharum albidum came last.

In the same Fig. 1, after 30 minutes of desiccation with silica gel, Thuidium gratum recorded the highest weight and was followed by Racopilum africanum. Coming next to this was Fissidens subglaucissimus which was then followed by Archidium ohioense. Bryum coronatum came up next while Octoblepharum albidum came last.

The desiccation after 1 hour as seen in Fig. 2, shows further decrease in weights. Both Racopilum africanum and Thuidium gratum recorded the highest weights with distilled water. This was followed by Fissidens subglaucis-

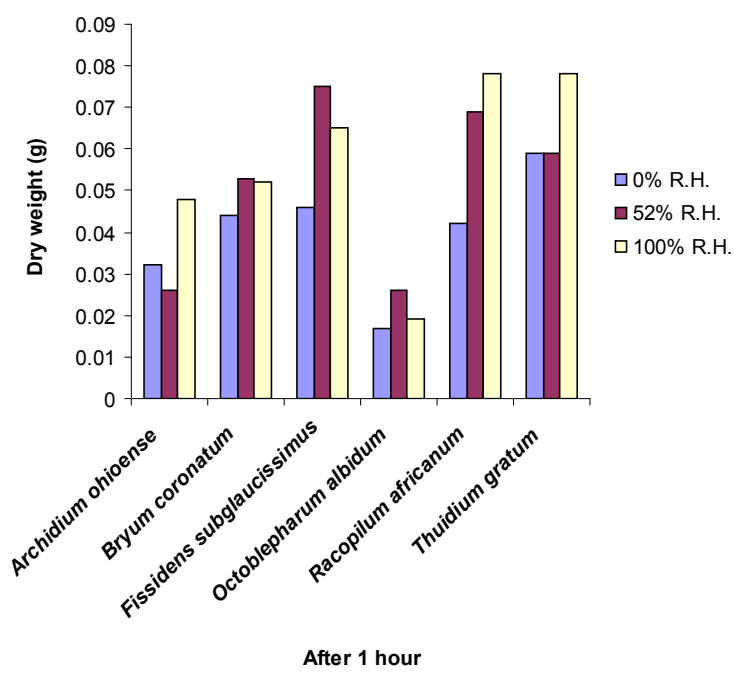

simus, Bryum coronatum and Archidium obioense while Octoblepharum albidum recorded least.

The desiccation with magnesium nitrate after 1 hour marked Fissidens subglaucissimus with the highest weight followed by Racopilum africanum and coming next to this was Thiudium gratum and then Bryum coronatum. Octoblepharum albidum was next while Archidium obioense was last.

The result of the weight after 1 hour desiccation with silica gel gave Thiudium gratum the highest weight while Fissiden subglaucissimus and Bryum coronatum followed closely and was followed by Archidium ohioense and Octoblepharum albidum came last.

Desiccation on the $8^{\text {th }}$ day with distilled water from Fig. 2 recorded the weight of Thuidium gratum as the highest. Coming next was Fissidens subglaucissimus and Bryum coronatum. Racopilum africanum followed and after come

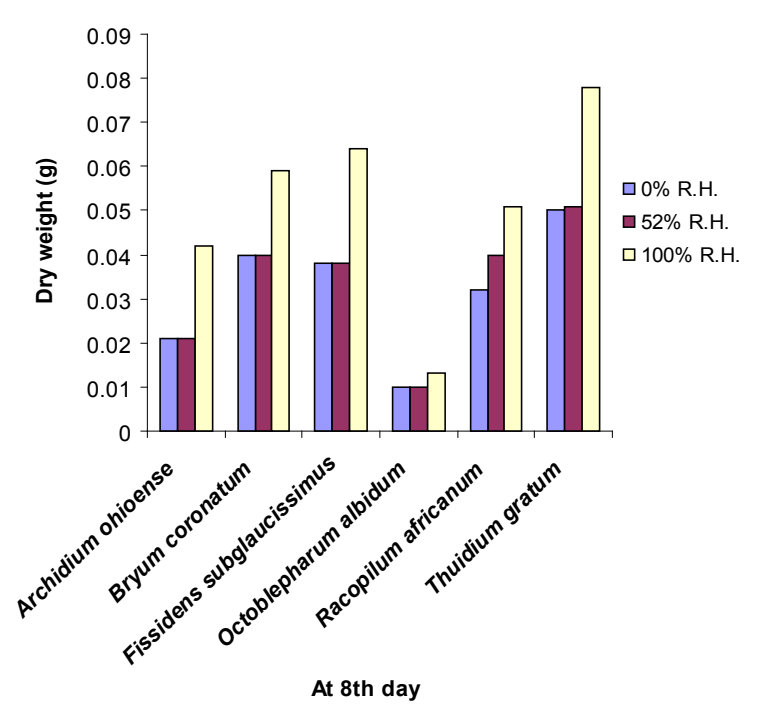

Fig. 2. Desiccation resistance in selected mosses 
42

Archidium obioense while Octoblepharum albidum came last.

With Magnesium nitrate on the $8^{\text {th }}$ day, Thuidium gratum had the highest weight and was closely followed by Fissidens subglaucissimus and Bryum coronatum. Then came next Archidium obioense leaving Octoblepharum albidum as the last.

On the $8^{\text {th }}$ day the desiccation with silical gel revealed Thuidium gratum with the highest weight and was followed by Fissidens subglaucissimus and Bryum coronatum. Coming next was Racopilum africanum and was followed by Archidium obioense while Octoblepharum albidum came last.

The summary from Fig. 1 and Fig. 2 show that there was a decrease in the dry weights more in the savanna species (Archidium obioense, Bryum coronatum and Fissidens subglaucissimus) than those of the forest species, except for Octoblepharum albidum that showed great decrease in its weight from 15 minutes interval to the $8^{\text {th }}$ day. At $0 \%$ relative humidity, a decrease in the rate of water loss was observed in all six mosses, but while Thuidium gratum a forest species lost about $50 \%$ of its weight, Octoblepharum albidum also forest species lost about $80 \%$ by the $8^{\text {th }}$ day. At $52 \%$ relative humidity, there was a general decrease in the rate of water loss for all six mosses, although the water loss was more in Octoblepharum albidum. The loss of water at $0 \%$ and $52 \%$ relative humidity by the $8^{\text {th }}$ day was equal in all the mosses except Thuidium gratum and Racopilum africanum.

\section{Discussion and conclusions}

Several workers have shown that the ability of bryophytes to withstand desiccation is correlated with the relative humidity of the atmosphere in which they grow (Clausen, 1952; Ochi, 1952; Abel, 1956). The current study in agreement is with this, as all the mosses studied except Racopilum africanum lost equal amount of water on the $8^{\text {th }}$ day at $0 \%$ and $52 \%$ relative humidity (Fig. 2). Makinde (1981), noted that forest mosses lost water than the derived savanna species. In this study, this was true of Octoblepharum albidum but not in Racopilum africanum and Thuidium gratum.

Bryophytes generally have no mechanism for water retention, especially at low humidities (Clausen, 1952). The study confirms this theory in Figs. 1 and 2, especially with Thuidium gratum which did not lose more than $50 \%$ of its water content.

As reported by Egunyomi $(1978 ; 1979)$, in Western Nigeria $O$. albidum is annually subjected to a prolonged dry season (November-March) alternating with a predominantly rainy season (April-October). During dry season the moss losses most of its water content, ceases growing, and survive in a quiescent dry state thus exhibiting a high tolerance to desiccation. This study agreed with this assertion ( Figs. 1 and 2 ).

In this study, the results show a relationship between the mosses with the rate of water loss and the relative humidity, as less water was lost at higher relative humidity.

In conclusion, it was realized that the variation of the location of the moss species and the thick cell walls noticed in all the selected mosses, are adaptations which must have helped them survived desiccation stress.

\section{References}

Abel, N. O. (1956). Die Auslrocknungsresistenzderhaubmoose. Sher. Ost. Akadiss. Math, naturu KI,Abt, 1:165-619.

Bohnert, H. J. (1995). Adaptations to environmental stresses. The Plant Cell. 7:1099-1111.

Clausen, E. (1952). A study of the occurrence of hepatics in a Danish iract and the influence of relative humidity on their distribution. Dansk Bot. Arkiv. 15:1-80.

Egunyomi, A. (1978). The distribution of the pantropical moss Octoblepharum albidum Hedw. in Africa with special reference to Nigeria. Revue Bryologie et lichenologie. 44(2):141-148.

Egunyomi, A. (1979). Autecology of Octoblepharum albidum Hedw. in Nigeria. II. Phenology and Water Relations Nova. Hedw. 31:377-389.

Gaff, D. F. (1989). Responses of desiccation tolerant resurrection plant to water stress, p. 255-268. In: Kreeb K. H., H. Richter, T. M. Hinchley (Eds). Structural and Functional Responses to Environmental Stresses: Water shortage. Berlin, XIV International Botanical Congress.

Makinde, A. and A. A. Fajuke (2009). Adaptive Strategies of Mosses to Desiccation. Notulae Botanicae Horti Agrobotanici Cluj-Napoca. 37(1):191-193.

Muller, H. A. (1979). The phylogeny and distribution of the Musci. In: Bryophyte Systematics, Clarke, G.C.G and Duckett, J. G. (Eds) Vol. 14:11-39, Academic Press N.Y.

Pammenter, N. W. and P. Berjak (1999). A review of recalcitrant seed physiology in relation to desiccation-tolerance mechanisms. Seed Science Research. 9:13-37.

Richards, P. W. (1984). The ecology of Tropical forest bryophytes. In: R. M. Schuster (ed), New Manual of Bryology. Hattori Botanical Laboratory Nichinan. 2:1233-1270.

Smirnoff, N. (1993). The role of active oxygen in the response of plants to water deficit and desiccation. New Phytologist. 125:27-58. 